\title{
Towards a backbone tree for Seimatosporium, with $S$. physocarpi sp. nov.
}
Chada Norphanphoun ${ }^{1,2}$, Sajeewa S. N. Maharachchikumbura ${ }^{3}$, Dinushani A. Daranagama $^{2,5}$,Timur S. Bulgakov ${ }^{6}$, Darbhe J. Bhat ${ }^{7,8}$, Ali H. Bahkali ${ }^{9}$, Kevin D. Hyde $^{1,2,4,8}$

${ }^{1}$ Key Laboratory for Plant Biodiversity and Biogeography of East Asia (KLPB), Kunming Institute of Botany, Chinese Academy of Science, Kunming 650201, Yunnan, China

${ }^{2}$ Institute of Excellence in Fungal Research, School of Science, Mae Fah Luang University, Chiang Rai 57100, Thailand

${ }^{3}$ Guizhou Key Laboratory of Agricultural Biotechnology, Guizhou Academy of Agricultural Sciences, Xiaohe District, Guiyang City, Guizhou Province 550006, People's Republic of China

${ }^{4}$ World Agroforestry Centre, East and Central Asia, 132 Lanhei Road, Kunming 650201, China

${ }^{5}$ State Key Laboratory of Mycology, Institute of Microbiology, Chinese Academy of Sciences, No 3 1st West Beichen Road, Chaoyang District Beijing 100101, People's Republic of China

${ }^{6}$ Academy of Biology and Biotechnology, Southern Federal University, Rostov-on-Don 344090, Rostov region, Russia

${ }^{7}$ Formerly Department of Botany, Goa University, Goa, India

${ }^{8}$ No. 128/1-J, Azad Housing Society, Curca, Goa Velha, India

${ }^{9}$ Department of Botany and Microbiology, College of Science, King Saud University, P.O. Box 2455, Riyadh 11451,Kingdom of Saudi Arabia

Norphanphoun C, Maharachchikumbura SSN, Daranagama A, Bulgakov TS, Bhat DJ, Bahkali AH, Hyde KD 2015 - Towards a backbone tree for Seimatosporium, with S. physocarpi sp. nov. Mycosphere 6(3), 385-400, doi 10.5943/mycosphere/6/3/12

\begin{abstract}
The genus Seimatosporium is saprobic or pathogenic on plants, and are 'pestalotioid fungi'. The genus presently belongs in Discosiaceae (Amphisphaeriales) and includes 78 species epithets. In this study, we observed three specimens of Seimatosporium from Russia and they are characterized by morphological and sequence data. We analyzed combined ITS and LSU gene sequence data of 42 species representing the genera Discostroma (7), Sarcostroma (2) and Seimatosporium (32, including the three new strains) with Pseudopestalotiopsis theae as the outgroup taxon. One isolate from dead branches of Physocarpus opulifolius is unique and is introduced as Seimatosporium physocarpi sp. nov., in this paper. It can be distinguished from similar and related species by phenotypic conidial characters and phylogenetic analyses. A specimen from Rosa kalmiussica Chrshan. \& Lasebna (often included in Rosa canina sensu lato) is designated as an epitype for $S$. rosae, the type of the genus. In addition, a collection of $S$. lichenicola is described, illustrated and compared with other species in the genus.
\end{abstract}

Key words - Discosiaceae - new species - phylogeny - epitype - combine gene - taxonomy.

\section{Introduction}

The genus Seimatosporium was introduced by Corda (1833), with $S$. rosae Corda as the type species. This genus is presently placed in the family the Discosiaceae, Amphisphaeriales (Senanayake et al. 2015). The sexual morph of Seimatosporium has been identified as Discostroma 
(Hyde et al. 2011) and are known as 'pestalotioid fungi' (Nag Raj 1993). Seimatosporium is a relatively well-known saprobic and plant pathogenic coelomycetous taxon (Sutton 1980, Tanaka et al. 2011). Based on their conidial features, Nag Raj (1993) provided an account of Seimatosporium species and rearranged them into five natural groupings under extant generic names. These are Seimatosporium sensu stricto (S. botan Sat. Hatak. \& Y. Harada), Sporocadus (with S. lichenicola (Corda) Shoemaker \& E. Müll., the generic type), Sarcostroma (with S. foliicola (Berk.) Shoemaker, as type of the genus), Diploceras (with S. hypericinum (Ces.) B. Sutton, as type of the genus), and Vermisporium (with S. leptospermi R.G. Bagn. \& Sheridan). Tanaka et al. (2011) restudied Diploceras, Sporocadus, Sarcostroma, Diploceras, and Vermisporium, which lack sexual morphs, and concluded that they should be placed under the genus Seimatosporium, based on a monophyletic grouping in LSU and ITS phylogenetic analyses. This finding was similar to the large diversity of Seimatosporium species as treated in Sutton (1980). According to Index Fungorum (2015) Seimatosporium comprises 78 species. The characteristic features of the genus are conidia with pigmented median cells, with or without an apical appendage, and single, branched or unbranched basal appendage (Nag Raj 1993).

In the present study, we report on three specimens of Seimatosporium, collected in Russia. With evidence from morphological and phylogenetic analyses we introduce a new species $S$. physocarpi; designate an epitype for $S$. rosae, and provide a detailed description for $S$. lichenicola which is the asexual morph of Discostroma fuscellum.

\section{Material \& Methods}

\section{Sample collection and specimen examination}

Samples were collected during May 2014 from the Rostov region of European Russia and returned to the laboratory in small paper bags. Specimens were examined under a Motic SMZ 168 dissecting microscope for fungal fruiting bodies. Hand sections of the fruiting structures were mounted in water for microscopic studies. The fungi were examined under a Nikon Ni compound microscope and photographed using a Canon EOS 600D digital camera fitted to the microscope. The images were processed with Adobe Photoshop CS5 Extended version 12.0 software (Adobe Systems Inc., The United States) and the Tarosoft (R) Image Frame Work program v. 0.9.7 was used for measurements. Single spore isolation was followed the method detailed in Chomnunti et al. (2014) and the germinating spores were transferred aseptically to malt extract agar (MEA) plates and incubated at $18{ }^{\circ} \mathrm{C}$. Colony characters were observed and measured after a week and one month.

The herbarium materials are deposited in the Mae Fah Luang University Herbarium, Chiang Rai, Thailand (MFLU) and New Zealand Fungal Herbarium, New Zealand (PDD) and living cultures deposited at Mae Fah Luang University Culture Collection (MFLUCC) and Fungal Biodiversity Centre (CBS). Facesoffungi numbers and Index Fungorum numbers are provided as detailed in Jayasiri et al. (2015) and Index Fungorum (2015).

\section{DNA extraction, PCR amplification and sequencing}

Genomic DNA were extracted from the growing mycelium on PDA, following the methods of Telle \& Thines (2011). Polymerase chain reactions (PCR) were carried out using primer pairs of ITS5 and ITS4 to amplify the internal transcribed spacers (ITS) (White et al. 1990), and large subunit rDNA (LSU) was amplified using primer pairs of LROR and LR5 (Vilgalys \& Hester 1990). The amplification reaction was performed in a $50 \mu$ reaction volume containing, 5-10 ng DNA, 0.8 units Taq polymerase, $1 \times$ PCR buffer, $0.2 \mathrm{mM}$ dNTP, $0.3 \mu \mathrm{m}$ of each primer with 1.5 $\mathrm{mM} \mathrm{MgCl} 2$ (Cai et al. 2009). Amplification protocols were followed according to Maharachchikumbura et al. (2013, 2014). The PCR products were visualized on 1\% agarose gel stained with ethidium bromide. Purification and sequencing of PCR product were carried at Shanghai Sangon Biological Engineering Technology \& Services Co., Ltd (China). Sequences derived from this study were deposited in GenBank. 


\section{Phylogenetic analysis}

Blast searches were made to identify the closest matches in GenBank (Table 1) and recently published sequences. Combined analysis of LSU and ITS sequences of 39 taxa of Discostroma (7), Sarcostroma (2) and Seimatosporium (29) were used to confirm the phylogenetic placement of our three strains, with Pseudopestalotiopsis theae (MFLUCC 12-0055) as the outgroup taxon. Sequence data were optimized manually to allow best alignment and maximum sequence similarity as detailed in Maharachchikumbura et al. (2012). A maximum parsimony analysis (MP) was performed using PAUP (Phylogenetic Analysis Using Parsimony) v. 4.0b10 (Swofford 2002). Ambiguously aligned regions were excluded and gaps were treated as missing data. The trees were inferred using the heuristic search option with TBR branch swapping and 1000 random sequence additions. Maxtrees were setup to 5000, branches of zero length were collapsed and all multiple parsimonious trees were saved. Descriptive tree statistics for parsimony Tree Length [TL], Consistency Index [CI], Retention Index [RI], Relative Consistency Index [RC] and Homoplasy Index [HI] were calculated for the Maximum Parsimonious Tree (MPT). The robustness of the most parsimonious trees was evaluated by 100 bootstrap replications resulting from maximum parsimony analysis, each with ten replicates of random stepwise addition of taxa (Felsenstein 1985).The Kishino-Hasegawa tests (KHT) (Kishino \& Hasegawa 1989) were performed to determine whether the trees were significantly different. Trees were viewed in TreeView v.1.6.6 (Page 1996)

In addition, Bayesian Analyses (BA) were performed using MrBayes 3.2.0 (MrBayes v. 3.2.1; Ronquist et al. 2012). Suitable models for the Bayesian analysis were first selected using models of nucleotide substitution for each gene, as determined using MrModeltest v. 2.2 (Nylander 2004), and included for each gene partition. The analyses of four Markov Chain Monte Carlo (MCMC) chains were run from random trees for 1,000,000 generations and sampled every 100 generations. The temperature value was lowered to 0.15 , burn-in was set to 0.10 , and the run was automatically stopped as soon as the average standard deviation of split frequencies reached below 0.01.The resulting trees were printed with FigTree v1.4.0 (http://tree.bio.ed.ac.uk/software/figtree/).

Table 1 GenBank Accession numbers of the sequences used in phylogenetic analysis

\begin{tabular}{|c|c|c|c|}
\hline \multirow{2}{*}{ Taxon name } & \multirow{2}{*}{ Strain number } & \multicolumn{2}{|c|}{ GenBank Acc. No. } \\
\hline & & $L S U$ & ITS \\
\hline \multirow{4}{*}{ Discostroma fuscellum (Berk. \& Broome) Huhndorf } & NBRC 32625 & AB593726 & AB594794 \\
\hline & NBRC 32680 & AB593739 & AB594806 \\
\hline & 10071 & - & AF377284 \\
\hline & 418-BB & - & GU244511 \\
\hline Discostroma sp. & HKUCC 1004 & AF382380 & - \\
\hline Discostroma stoneae (H.J. Swart) Sivan. & NBRC 32690 & AB593729 & AB594797 \\
\hline Discostroma tostum (Berk. \& Broome) Brockmann & NBRC 32626 & AB593727 & AB594795 \\
\hline $\begin{array}{l}\text { Pseudopestalotiopsis theae (Sawada) Maharachch., K.D. } \\
\text { Hyde \& Crous }\end{array}$ & MFLUCC 12-0055 & KM116282 & JQ683727 \\
\hline Sarcostroma bisetulatum (Guba) Nag Raj & CBS 122695 & - & EU552155 \\
\hline \multirow[t]{2}{*}{ Sarcostroma restionis S.J. Lee \& Crous } & CBS 118153 & DQ278925 & DQ278923 \\
\hline & CBS 118154 & DQ278924 & DQ278922 \\
\hline $\begin{array}{l}\text { Seimatosporium biseptatum (H.J. Swart \& M.A. Will.) P.A. } \\
\text { Barber \& Crous }\end{array}$ & СРC 13584 & JN871208 & JN871199 \\
\hline Seimatosporium botan Sat. Hatak. \& Y. Harada & H4619 & AB593731 & AB594799 \\
\hline \multirow[t]{3}{*}{ Seimatosporium discosioides (Ellis \& Everh.) Shoemaker } & $\mathrm{H} 4621$ & AB593732 & AB594800 \\
\hline & KACC 42490 & - & EF600969 \\
\hline & KACC 42491 & - & EF600970 \\
\hline Seimatosporium elegans H.J. Swart & NBRC 32674 & AB593733 & AB594801 \\
\hline \multirow[t]{4}{*}{ Seimatosporium eucalypti (McAlpine) H.J. Swart } & CPC 156 / CBS 115131 & JN871209 & JN871200 \\
\hline & CPC 157 / CBS 110733 & JN871210 & JN871201 \\
\hline & CPC 158 / CBS 110734 & JN871211 & - \\
\hline & CPC 159 / CBS 114876 & JN871212 & JN871202 \\
\hline \multirow[t]{3}{*}{ Seimatosporium falcatum (B. Sutton) Shoemaker } & CPC 13580 & JN871214 & JN871205 \\
\hline & CPC 12992 & - & JN871203 \\
\hline & CPC 13578 & JN871213 & JN871204 \\
\hline Seimatosporium foliicola (Berk.) Shoemaker & NBRC 32676 & AB593734 & AB594802 \\
\hline
\end{tabular}




\begin{tabular}{|c|c|c|c|}
\hline \multirow{2}{*}{ Taxon name } & \multirow{2}{*}{ Strain number } & \multicolumn{2}{|c|}{ GenBank Acc. No. } \\
\hline & & $L S U$ & ITS \\
\hline \multirow{2}{*}{$\begin{array}{l}\text { Seimatosporium glandigenum (Bubák \& Gonz. Frag.) B. } \\
\text { Sutton } \\
\text { Seimatosporium grevilleae (Loos) Shoemaker }\end{array}$} & NBRC 32677 & AB593735 & AB594803 \\
\hline & ICMP 10981 & AF382372 & AF405304 \\
\hline \multirow{3}{*}{$\begin{array}{l}\text { Seimatosporium hakeae (B. Sutton) Shoemaker } \\
\text { Seimatosporium hypericinum (Ces.) B. Sutton } \\
\text { Seimatosporium kriegerianum (Bres.) Morgan-Jones \& B. } \\
\text { Sutton }\end{array}$} & NBRC 32678 & AB593736 & AB594804 \\
\hline & NBRC 32647 & AB593737 & AB594805 \\
\hline & NBRC 32679 & AB593738 & - \\
\hline Seimatosporium leptospermi R.G. Bagn. \& Sheridan & ICMP 11845 & AF382373 & - \\
\hline Seimatosporium lichenicola (Corda) Shoemaker \& E. Müll. & MFLUCC $14-0623$ & KT198725 & KT198724 \\
\hline Seimatosporium mariae (Clinton) Shoemaker & NBRC 32681 & AB593740 & AB594807 \\
\hline $\begin{array}{l}\text { Seimatosporium obtusum (H.J. Swart \& M.A. Will.) P.A. } \\
\text { Barber \& Crous }\end{array}$ & CPC 12935 & JN871215 & JN871206 \\
\hline \multirow{2}{*}{$\begin{array}{l}\text { Seimatosporium parasiticum (Dearn. \& House) Shoemaker } \\
\text { Seimatosporium physocarpi C. Norphanphoun, Bulgakov \& } \\
\text { K.D. Hyde }\end{array}$} & NBRC 32682 & AB593741 & AB594808 \\
\hline & MFLUCC 14-0625 & KT198723 & KT198722 \\
\hline \multirow[t]{2}{*}{ Seimatosporium pistaciae Crous \& Mirab. } & $\begin{array}{l}\mathrm{CPC} 24455 / \mathrm{CBS} \\
138865\end{array}$ & КР004491 & KP004463 \\
\hline & CPC 24457 & KP004492 & KP00 \\
\hline Seimatosporium rosae Corda & MFLUCC $14-0621$ & KT198727 & KT198726 \\
\hline Seimatosporium sp. & HKUCC 7986 & AF382375 & - \\
\hline Seimatosporium vaccinii (Fuckel) B. Erikss. & ICMP 7003 & AF382374 & - \\
\hline $\begin{array}{l}\text { Seimatosporium walkeri (H.J. Swart \& M.A. Will.) P.A. } \\
\text { Barber \& Crous }\end{array}$ & CPC 17644 & JN871216 & JN871207 \\
\hline
\end{tabular}

CBS: Culture collection of the Centraalbureau voor Schimmelcultures, Fungal Biodiversity Centre, Utrecht, The Netherlands; CPC: Culture collection of Pedro Crous, housed at CBS; H: Finnish Museum of Natural History (University of Helsinki), HKUCC: The University of Hong Kong Culture Collection, Hong Kong, China; ICMP: International Collection of Microorganisms from Plants, Auckland, New Zealand; KACC: Korean Agricultural Culture Collection, National Institute of Agricultural Biotechnology, Korea; MFLUCC: Mae Fah Luang University Culture Collection, Chiang Rai, Thailand; NBRC: Biological Resource Center, National Institute of Technology and Evaluation, Chiba, Japan; LSU: large subunit (28S) of the nrRNA gene operon; ITS: internal transcribed spacers and intervening 5.8S nrDNA.

\section{Results}

\section{Phylogenetic analyses}

The combined LSU and ITS alignment was used to resolve the species relationships in Seimatosporium. The phylogenetic analyses were obtained from maximum parsimony (MP) and Bayesian analyses. The alignment comprised 42 taxa and 1300 total characters including gaps. Parsimony analyses indicate that 1140 characters were constant, 73 variable characters were parsimony-uninformative and 87 characters were parsimony informative. The parsimony analysis of the data matrix resulted in two equally parsimonious trees and in the first tree $(\mathrm{TL}=288$, $\mathrm{CI}=0.670, \mathrm{RI}=0.814, \mathrm{RC}=0.546, \mathrm{HI}=0.330$ ) is shown here. The Bayesian analysis resulted in a tree with the same topology as the MP trees. The phylogenetic results from Fig. 1 are discussed in the descriptive notes and discussion below.

\section{Taxonomy}

Seimatosporium lichenicola (Corda) Shoemaker \& E. Müll., Can. J. Bot. 42: 405 (1964) Fig. 2 Faces of fungi numbers: FoF00793

Asexual morph - Discostroma fuscellum (Berk. \& Broome) Brockmann 1976

Saprobic and parasitic on dying twigs, leaf stalks and leaves, sometimes on living leaves of Cotinus coggygria Scop. Sexual morph: Undetermined. Asexual morph: Conidiomata 400-600 $\mu \mathrm{m}$ diam. pycnidial, solitary, immersed, unilocular, brown, with a conspicuous apex. Pycnidial wall (30-50 $\mu \mathrm{m}$ ) multilayered, comprised of light brown-walled cells of textura angularis, with inner most layer thin, hyaline. Conidiophores reduced to conidiogenous cells. Conidiogenous cells holoblastic, phialidic, hyaline, smooth, formed from the inner most layer of pycnidium wall. Conidia (10-)12- 


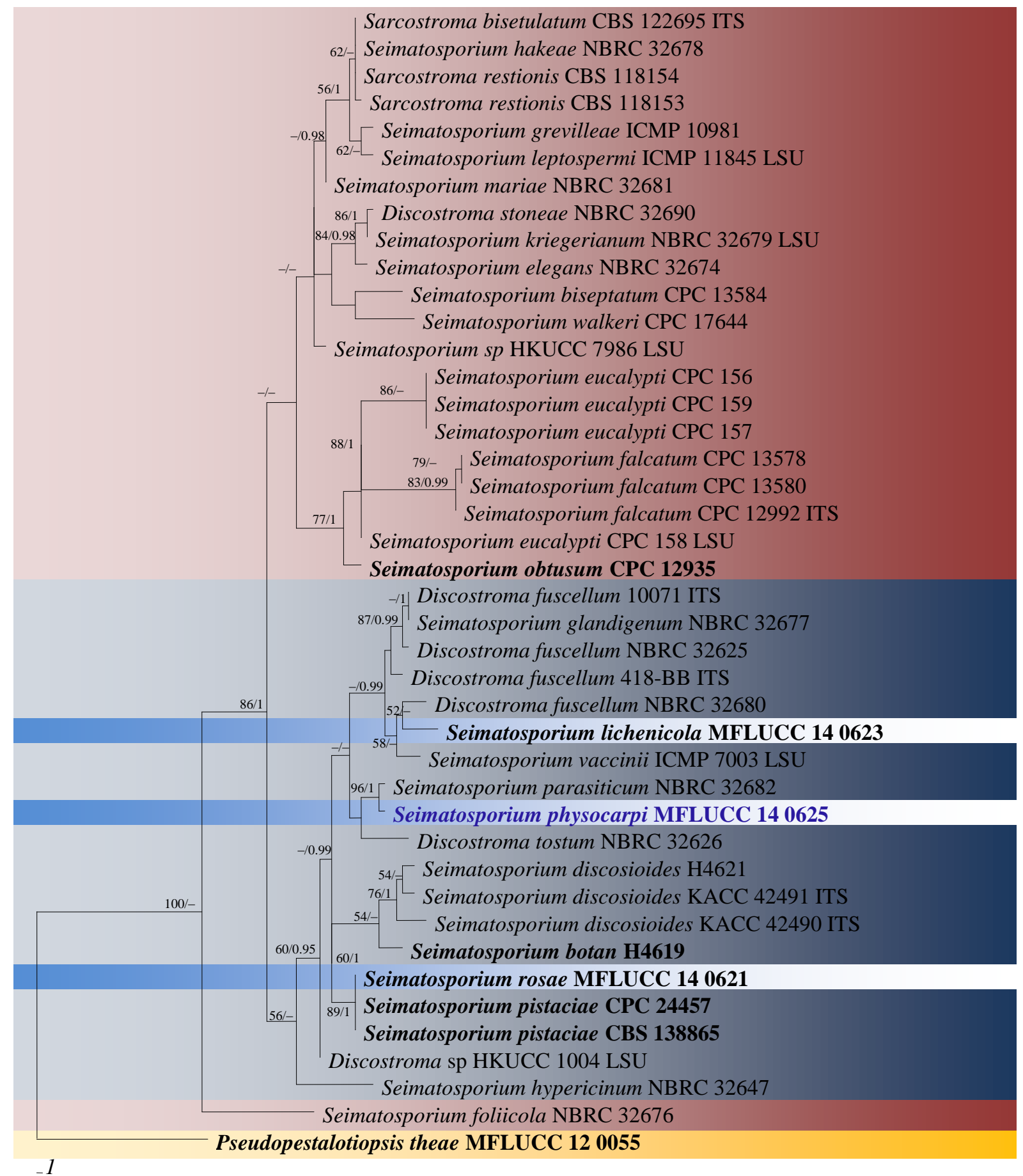

Fig. 1 - Maximum Parsimony (MP) majority rule consensus tree for the analyzed Seimatosporium isolates based on a combined dataset of LSU and ITS sequence data. MP bootstrap support values higher than 50\% and Bayesian posterior probabilities (PP) above $95 \%$ are given at the nodes (MP/PP). The tree is rooted with Pseudopestalotiopsis theae (MFLUCC 12-0055). The strain numbers are mentioned after the species names. New strains are in blue bold and ex-type strains are in black bold.

$14 \times 4-5(-6) \mu m(\bar{x}=12 \times 5 \mu m, \mathrm{n}=30)$, initially hyaline, pale brown to dark brown at maturity, fusiform, straight, infrequently slightly curved, with 3 transverse septa, not constricted at the septa, narrowly rounded at both ends, smooth-walled, with thick walls pale brown to dark brown at maturity, narrowly rounded at both ends, smooth-walled, basal cell conic to obconic with a truncate base, subhyaline, $2.5-4 \mu \mathrm{m}$ long $(\bar{x}=3.5 \mu \mathrm{m})$, with two median cells subcylindrical to doliform, with thick verruculose walls, brown to dark brown, 7.5-8 $\mu \mathrm{m}$ long $(\bar{x}=7.5 \mu \mathrm{m})$, with apical cell conical and rounded at apex, hyaline, cylindrical to subcylindrical, $3.5-4 \mu \mathrm{m}$ long $(\bar{x}=3.5 \mu \mathrm{m})$. 

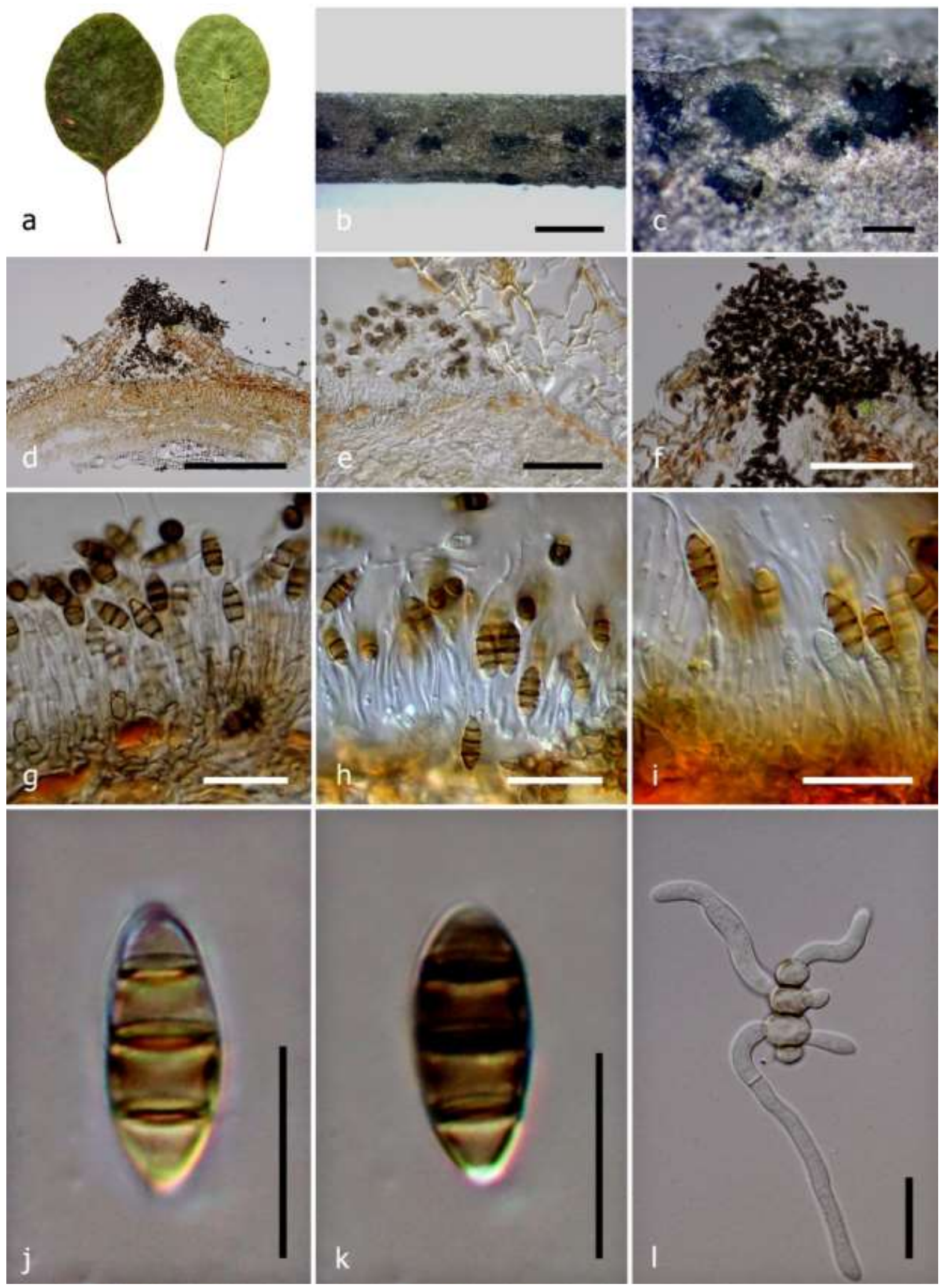

Fig. 2 - Seimatosporium lichenicola (MFLUCC 14-0623). a Leaf spot disease on Cotinus coggygria leaf. b Habit on wood. c Fruiting bodies on substrate. The blackened areas are the conidia masses. d Cross section of the conidioma. e Pycnidial wall. f Apex of conidioma. g, h, i Conidiogenous cells. j, k Mature conidia. 1 Germinating spore on PDA. Bars: $\mathrm{d}=300 \mu \mathrm{m}$; $\mathrm{e}=50$ $\mu m ; \mathrm{f}=100 \mu m ; \mathrm{g}, \mathrm{h}, \mathrm{i}, \mathrm{l}=20 \mu \mathrm{m} ; \mathrm{j}, \mathrm{k}=10 \mu \mathrm{m}$. 
Culture characters - Colonies on PDA slow growing, reaching $2 \mathrm{~cm}$ diam. after 5 days at $25{ }^{\circ} \mathrm{C}$, circular, spreading, with flat mycelium, with fimbriate margins, pale yellow clusters forming in the centre of colonies after 2 days, clustered or effuse in centre of colony, lacking aerial mycelium.

Material examined - RUSSIA, Rostov Region, Oktyabrsky District, Persianovsky Arboretum, on live leaves and dying branches of Cotinus coggygria Scop, 4 June 2014, T. Bulgakov T-095 (MFLU 14-0773, reference specimen of Seimatosporium lichenicola designated here), living culture, MFLUCC 14-0623, CBS 139966.

Notes - Seimatosporium lichenicola was introduced by Shoemaker \& Müller (1964) as the sexual morph of Clethridium corticola (Fuckel) Shoemaker \& E. Müll. The species was described as coelomycetous, producing clavate, mostly 3 transversely septate, non-seteferous conidia. Sutton (1980) reported S. lichenicola, with 13-15 × 5.5-6.5 $\mu \mathrm{m}$, 3-septate, fusiform conidia, which lack appendages. Nag Raj (1993) transferred S. lichenicola to Sporocadus. The type was from Rosa canina, in Lobkowitschen gardens in Prague, Czechoslovakia. Tanaka et al. (2011) reviewed these four genera and as none had a reported sexual morph, they were synonymized under Seimatosporium. The sexual morph of S. lichenicola is reported to be Discostroma fuscellum based on phylogenetic data (Tanaka et al. 2011).

Our collection is consistent with the reports of Shoemaker \& Müller (1964), Sutton (1980), Nag Raj (1993) and Tanaka et al. (2011), whereas our collection differs in being found on dead branches of Cotinus coggygria in Russia. Based on these findings, we name our collection as $S$. lichenicola. Molecular analyses show our strain to cluster with Discostroma fuscellum which is the sexual morph of S. lichenicola (Fig. 1) (Tanaka et al. 2011, Nag Raj 1993). Sequence data for $S$. lichenicola is not available in GenBank and therefore, we designate our collection as a reference specimen. We do not designate an epitype as the host is different (Ariyawansa et al. 2014).

Seimatosporium physocarpi C. Norphanphoun, Bulgakov \& K.D. Hyde, sp. nov. Index Fungorum Number: IF551287

Faces of fungi number: FoF00794

Etymology - Physocarpi, refers to the the host genus from which this species was collected.

HOLOTYPUS: MFLU 14-0775.

Parasitic (necrotrophic) and saprobic on leaves (leaf spot), twigs and fruits of Physocarpus opulifolius. Sexual morph: Undetermined. Asexual morph: Conidiomata stromatic, erumpent, initially subglobose, becoming cornuted with an obtuse or subcylindrical head and a broad stalk, up to 350-900 $\mu \mathrm{m}$ diam, 400-900 $\mu \mathrm{m}$ high, globose, pale brown to brown, dehiscing by a rupture in the overlying host epidermis and covered with dark brown conidial masses. Pycnidial wall basal stroma up to $200 \mu \mathrm{m}$ thick, with cell of textura angularis, moderately thick-walled, hyaline. Conidiophores arising from the upper cells of the basal stroma, branched, hyaline, smooth, up to 20 $\mu m$ long, invested in mucus. Conidiogenous cells lageniform to subcylindrical with moderate apical periclinal thickening, hyaline, smooth, formed from the inner most layer of pycnidial. Conidia (10)15-16 $\times 3.5-4.8(5) \mu m(\bar{x}=13 \times 4.1 \mu \mathrm{m}, \mathrm{n}=30)$, hyaline to slightly olivaceous, fusiform, straight to slightly curved, 3-septate, basal cell conic to obconic, slightly olivaceous, thin-walled and verruculose, $2-3 \mu \mathrm{m}$ long $(\bar{x}=2.5 \mu \mathrm{m})$, with two median cells, doliiform to cylindrical, with thick verruculose walls, constricted at the septa, concolourous, olivaceous, with septa and periclinal walls darker than the rest of the cell, together 5.5-8 $\mu \mathrm{m}$ long $(\bar{x}=6.75 \mu \mathrm{m})$, second cell from base 3.5-4 $\mu m(\bar{x}=3.7 \mu \mathrm{m})$; third cell $2-3.5 \mu m(\bar{x}=2.75 \mu \mathrm{m})$; apical cell hyaline, cylindrical to subcylindrical 2-3 $\mu \mathrm{m}$ long $(\bar{x}=2.5 \mu \mathrm{m})$; with 1 tubular apical appendage, arising from the apex of the apical cell, $7-12 \mu \mathrm{m}$ long $(\bar{x}=9.5 \mu \mathrm{m})$, unequal in length; basal appendage present, rarely one, 12- $14 \mu \mathrm{m}$ long $(\bar{x}=13 \mu \mathrm{m})$.

Culture characteristics - Colonies on PDA slow growing, reaching $2.5 \mathrm{~cm}$ diam. after 7 days at $25{ }^{\circ} \mathrm{C}$, later producing dense mycelium, circular, erumpent, spreading, fluffy, with moderate aerial mycelium and smooth, margins lobate, pale yellow in the centre of the colony after 4 days, clustered or effuse on center of colony surface, without aerial mycelium. 

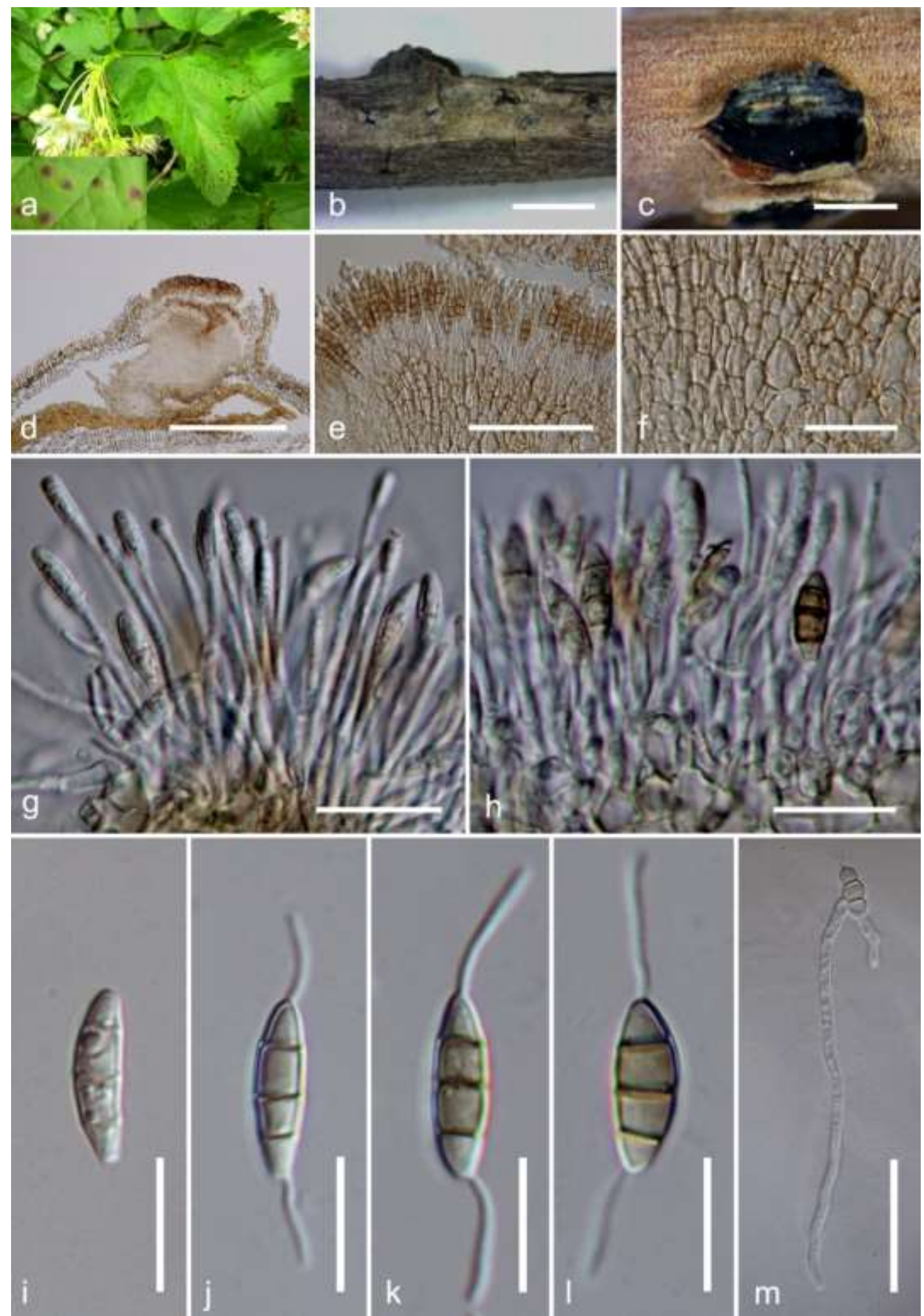

Fig. 3 - Seimatosporium physocarpi (holotype) a Leaf spot disease on Physocarpus opulifolius leaf. $\mathrm{b}$ Stromatal habit in wood. $\mathrm{c}$ Fruiting bodies on host substrate. d Cross section of the stroma showing perithecia. e, f Peridium. g, h Conidiogenous cells. i Immature conidia. j, k, 1 Mature conidia. $\mathrm{m}$ Germinating spore on PDA. - Bars: $\mathrm{c}=600 \mu \mathrm{m} ; \mathrm{d}=300 \mu \mathrm{m} ; \mathrm{e}, \mathrm{m}=50 \mu \mathrm{m} ; \mathrm{f}=20 \mu \mathrm{m}$; $\mathrm{g}, \mathrm{h}=15 \mu \mathrm{m} ; \mathrm{i}, \mathrm{j}, \mathrm{k}, \mathrm{l}=10 \mu \mathrm{m}$.

Material examined - RUSSIA, Rostov Region, Rostov-on-Don city, Botanical Garden of Southern Federal University, Systematic Arboretum, on dead branches of Physocarpus opulifolius (L.) Maxim (host family), 8 May 2014, T. Bulgakov T-126 (MFLU 14-0775, holotype); Ibid. (PDD, isotype); ex-type living culture, MFLUCC 14-0625, CBS 139968. 
Notes - In the phylogenetic tree (Fig. 1), S. physocarpi clustered in the same clade with $S$. parasiticum, Discostroma tostum (S. passerinii), S. lichenicola (D. fuscellum), S. glandigenum and $S$. vacinii. However, the conidia of $S$. passerinii, S. lichenicola, S. glandigenum and $S$. vacinii lack appendages, while only $S$. parasiticum has apical and basal appendages (Nag Raj 1993). Therefore our species morphologically closely resembles S. parasiticum. Seimatosporium parasiticum was described from leaves of Physocarpus opulifolius (Rosaceae) from Germany (Sutton 1980). However, $S$. physocarpi can be distinguished by its smaller conidial dimensions $(10-16 \times 3.5-4.8$ $\mu m$ in $S$. physocarpi, 22-35 $\times$ 5-7 $\mu \mathrm{m}$ in $S$. parasiticum) and $S$. physocarpi has longer apical (7-12 $\mu \mathrm{m}$ versus 2-5 $\mu \mathrm{m})$ and longer basal appendages (12-14 $\mu \mathrm{m}$ versus 2-8 $\mu \mathrm{m}$ ) than $S$. parasiticum (Sutton 1980). Our new species has 3-septate conidia and occurs in European Russia (and Eastern Europe). It is distinct from $S$. parasiticum which occurs in Central Europe, and has 3-5-septate (mostly 5-septate) and often irregularly curved conidia (Sutton 1980, Tomoshevich 2012). A detailed morphology comparison of the related species with the new species is provided in Table 2 .

This species is parasitic usually causes leaf spots of Physocarpus species, and also grows on dead twigs as with many necrotrophic fungi. Seimatosporium species found on Physocarpus spp. in some regions of European Russia (Moscow and Moscow region, St.-Petersburg and Leningrad region,, Rostov region, Krasnodar region) and Asian Russia (Western Siberia, Novosibirsk region) (Bulgakov et al. 2014, Tomoshevich 2012). In some reports, the Seimatosporium species on Physocarpus were reported as Seimatosporium lonicerae (Cooke) Shoemaker, but this species is distinct from $S$. physocarpi by occasionally having 2-septate conidia, with mostly a single basal appendage, and sometimes with a shorter apical appendage (Melnik 1997, Nag Raj 1993).

Seimatosporium rosae Corda, in Sturm, Deutschl. Fl., 3 Abt. (Pilze Deutschl.) 3(13): 79 (1833).

Index Fungorum Number: IF190497

Fig. 4

Epitypification identifier: IF551303

Faces of fungi numbers: FoF00795

Type: CZECHOSLOVAKIA, Prague, Pobaba, on stems of Rosa canina L. (PRM); (ex-type collection IMI 108309).

Saprobic and weak parasitic on dead and dying branches of Rosa kalmiussica Chrshan. \& Lasebna (this species often includes in Rosa canina sensu lato) Sexual morph: Undetermined. Asexual morph: Conidiomata acervular, intra-epidermal, 250-400 $\mu \mathrm{m}$ diam., 150-170 $\mu \mathrm{m}$ high, unilocular, glabrous, brown, dehiscing by irregular split in the overlying host tissue; basal stroma thin, with cells moderately thick-walled, almost colourless at the base, pale brown in the lateral tissue and cells of textura angularis. Conidiophores arising from the upper cells of the basal and lateral tissue, sparsely septate and branched, colourless, thin-walled, smooth, up to $10 \mu \mathrm{m}$ long. Conidiogenous cells lageniform to cylindrical, colourless, thin-walled,smooth, formed from the inner most layer of pycnidium wall. Conidia $(11-) 12-15 \times 3.5-4.5(-5) \mu \mathrm{m}(\bar{x}=13.5 \times 4.5 \mu \mathrm{m}, \mathrm{n}=$ 30 ), hyaline or slightly olivaceous, fusiform, straight to slightly curved, 3 -septate, basal cell conic to obconic, thin-walled and verruculose, 2-3.5 $\mu \mathrm{m}$ long $(\bar{x}=3 \mu \mathrm{m})$, with two median cells, doliiform to cylindrical, with thick verruculose walls, constricted at septa, concolourous, olivaceous, with septa and periclinal walls darker than the rest of the cell, together 5-7 $\mu \mathrm{m}$ long ( $\bar{x}$ $=17 \mu \mathrm{m})$ second cell from base 3-4.5 $\mu \mathrm{m}(\bar{x}=4 \mu \mathrm{m})$; third cell 3-4 $\mu \mathrm{m}(\bar{x}=3.5 \mu \mathrm{m})$; apical cell hyaline, cylindrical to subcylindrical 2.5-4 $\mu \mathrm{m}$ long $(\bar{x}=3.25 \mu \mathrm{m})$; with 1 tubular apical appendage, arising from the apex of the apical cell, 5-10(-10.4) $\mu \mathrm{m}$ long $(\bar{x}=8 \mu \mathrm{m})$, unequal in length; basal appendage present, 5-7(-8) $\mu \mathrm{m}$ long $(\bar{x}=5.5 \mu \mathrm{m})$.

Culture characteristics - Colonies on PDA slow growing, reaching $3 \mathrm{~cm}$ diam. after 13 days at $25{ }^{\circ} \mathrm{C}$, later producing dense mycelium, circular, rough margin white at first with dark green clusters in the center of the colony after 5 days, clustered or effuse on center of colony surface, without aerial mycelium. Hyphae septate branched, hyaline, thin. 



$\mathrm{m}$

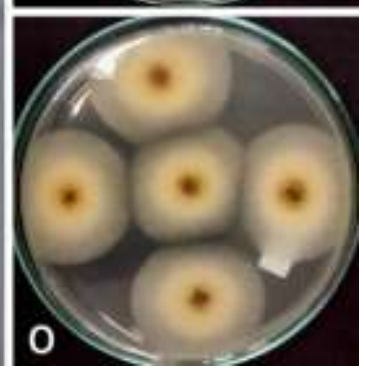

Fig. 4 - Seimatosporium rosae (epitype). a Habit in wood. b, c Fruiting bodies on host substrate. d Cross section of fruiting body. e, f Peridium. g, h, i Conidiogenous cells. j, k, 1 Mature conidia. m Germinating spore on PDA. $\mathrm{n}$ from above. o from below. Bars: $\mathrm{c}=200 \mu \mathrm{m} ; \mathrm{d}=300 \mu \mathrm{m}$; e, $\mathrm{g}, \mathrm{h}, \mathrm{i}$, $\mathrm{m}=20 \mu \mathrm{m} ; \mathrm{f}=50 \mu \mathrm{m} ; \mathrm{j}, \mathrm{k}, \mathrm{l}=10 \mu \mathrm{m}$.

Material examined - RUSSIA, Rostov Region, Krasnosulinsky District, Donskoye Forestry, edge of ravine forest, on dying and dead branches of Rosa kalmiussica Chrshan. \& Lasebna, 21 May 2014, T. Bulgakov T-056 (MFLU 14-0771, epitype of Seimatosporium rosae designated here); living cultures MFLUCC 14-0621, CBS 139823.

Notes - Seimatosporium rosae is the generic type and was found on Rosa canina (L.) from Podbaba in Prague (Corda 1833). Our isolate was collected on Rosa kalmiussica Chrshan. \& 
Lasebna from the Rostov Region of Russia and has the same conidial size range $(11-15 \times 3.5-5$ $\mu m$ ) and same host as S. rosae, which is consistent with reports of Sutton (1980), and Nag Raj (1993). In molecular analyses (Fig. 1), our isolate clusters together with $S$. pistaciae, a species introduced by Crous \& Mirab (2014) from buds of Pistacia vera from Iran. Although, S. pistaciae morphologically closely matches $S$. rosae, Crous \& Mirab distinguished these taxa, the former having larger conidia (15-22 × 4-5 $\mu \mathrm{m}$, Crous et al. 2014). We designate our collection of $S$. rosae as an epitype specimen (sensu Ariyawansa et al. 2014) as it was collected on same host in Europe.

\section{Discussion}

The genus Seimatosporium previously belonged in the family Amphisphaeriaceae (Shoemaker \& Müller 1964, Brockmann 1976, Paulus et al. 2006, Maharachchikumbura et al. 2015) and later transferred to newly introduced Discosiaceae (Senanayake et al. 2015). Amphisphaeriaceae was established by Winter (1887) as a large heterogeneous family which mainly contains Pestalotiopsis-like asexual morphs (Jeewon et al. 2002). These taxa are characterized by ascomata immersed in the host, with dark peridial walls and asci with amyloid apical apparatii (Barr 1975). Their asexual morphs are generally characterized by coelomycetous conidiomata producing septate conidia with filiform apical appendages (Barr 1990, Nag Raj 1993). Nag Raj (1993) has reported conidia with pigmented median cells, with or without one apical and basal appendage. The present findings that species of Vermisporium, characterized by their falcate to elongate-fusiform conidia with pigmented cells, a beak-like apical cell, and a podiform, tubular, unbranched, eccentric basal appendage, clustering in Seimatosporium was rather unexpected. Nag Raj (1993) has reported that one of the main characters used for distinguishing species was the length to width ratio, even though this had previously been found to be inadequate (Swart \& Williamson 1983). The taxonomy has traditionally placed a great deal of emphasis on length and width of conidia, while distinguishing species in Pestalotiopsis (Jeewon et al. 2003), and Seimatosporium, as a genus sharing many similarities. Spore length has been used as a key character, with many new species of Pestalotiopsis being described based on subtle differences in spore size (Mordue 1985, 1986, Nag Raj 1985, 1986, Venkatasubbaiah et al. 1991). Further, this finding also questions the value of appendage type sensu Nag Raj (1993) as informative features at generic level.

Sutton (1980) treated Seimatosporium as heterogeneous with a broad concept. However, Nag Raj (1993) segregated Seimatosporium in to five genera based on the conidial morphology. Therefore, the generic concept of Seimatosporium remains unresolved and this was discussed by Tanaka et al. (2011) with the support of molecular data. In their study, Tanaka et al. (2011), included isolates representing all the five genera discussed by Nag Raj (1993) and strains representing Seimatosporium sensu stricto. They observed that all Seimatosporium species and Discostroma sexual morphs clustered in a monophyletic group, but with several subgroups among the Seimatosporium sensu lato clade. These may be related to the colour of median cells and may have taxonomic value. For example, in the present study, the clade represented by Sarcostroma bisetulatum, S. restionis, Seimatosporium hakeae, S. grevilleae, S. leptospermi and S. mariae has coloured median cells. Its sister clade represented by Seimatosporium kriegerianum, S. elegans, $S$. biseptatum, Seimatosporium walkeri, S. eucalypti S. falcatum and S. obtusum however, have hyaline median cells. The colour of the median cells in Pestalotiopsis (Amphisphaeriales) has been shown to have taxonomic value, and based on pigmentation the genus was segregated in Pestalotiopsis, Neopestalotiopsis and Pseudopestalotiopsis (Maharachchikumbura et al. 2014). The same approach may helpful in the subdivision of Seimatosporium. However, further sampling of more genera/species, fresh collection with type strains, and establishing asexual and sexual morph connections are required for reassessment of this genus complex. In addition species of Discostroma and Seimatosporium have been linked by molecular data (Tanaka et al. 2011), however the molecular links have not been shown for the types of either genera. Both names should therefore be retained pending fresh collections of the types and further molecular study (Maharachchikumbura et al. 2015). 
Table 2 Synopsis of morphological features of species of Seimatosporium (Related to this research)

\begin{tabular}{|c|c|c|c|c|c|c|c|c|}
\hline \multirow[b]{2}{*}{ Species } & \multirow[b]{2}{*}{ Host } & \multirow[b]{2}{*}{$\begin{array}{c}\text { Conidioma } \\
\text { ta }(\mu \mathrm{m})\end{array}$} & \multicolumn{5}{|c|}{ Conidia } & \multirow[b]{2}{*}{ Reference } \\
\hline & & & Septate & Conidia size $(\mu \mathrm{m})$ & $\begin{array}{l}\text { Two median } \\
\text { cell }(\mu \mathrm{m})\end{array}$ & $\begin{array}{c}\text { Apical } \\
\text { appendage } \\
(\mu \mathrm{m})\end{array}$ & $\begin{array}{c}\text { Basal } \\
\text { appendage } \\
(\mu \mathrm{m})\end{array}$ & \\
\hline Seimatosporium botan & $\begin{array}{l}\text { Paeonia suffruticosa } \\
\text { (stems) }\end{array}$ & - & 3 septate & $16-20 \times 4-5$ & $8-11$ & $4-8$ & $4-8$ & $\begin{array}{l}\text { Duan et al., } \\
\quad(2011)\end{array}$ \\
\hline S. discosioides & Rosa heliophila (leaves) & $100-200$ & 3 septate & $11.5-18 \times 3.5-5$ & $7.5-10$ & $2-7$ & $2-6$ & Sutton, 1980 \\
\hline S. glandigenum & Quercus ballota, & $>250$ & 3 septate & $15-18 \times 5-6.5$ & $7.5-10$ & None & None & Sutton, 1980 \\
\hline S. lichenicola & Rosa sp. & $>350$ & 3 septate & $13-15 \times 5.5-6.5$ & - & None & None & Sutton, 1980 \\
\hline S. lonicerae & $\begin{array}{l}\text { Physocarpus opulifolius } \\
\text { (twigs) }\end{array}$ & 150 & 2-3 septate & $11-19 \times 3-5$ & $6.5-10$ & $4-10$ & $2-9$ & Sutton, 1980 \\
\hline $\begin{array}{l}\text { S. lichenicola } \\
\text { (MFLUCC 14-0623) }\end{array}$ & $\begin{array}{l}\text { Cotinus coggygria (dying } \\
\text { branches, live leaves) }\end{array}$ & $400-600$ & 3 septate & $\begin{array}{c}(10-) 12-14 \times 4- \\
5(-6)\end{array}$ & $7.5-8$ & None & None & In this study \\
\hline S. parasiticum & $\begin{array}{l}\text { Physocarpus opulifolius } \\
\text { (leaves) }\end{array}$ & $>100$ & $\begin{array}{c}3-5 \text { septate } \\
\text { (mostly } 5 \\
\text { septate) }\end{array}$ & $24-31 \times 4.5-6.5$ & $17-24$ & $1-8.5$ & $1.5-9$ & Sutton, 1980 \\
\hline S. passerinii & Epilobium fleischeri & $400-800$ & 3 septate & $14-20 \times(3-2)-4$ & - & $10-18$ & None & $\begin{array}{l}\text { Syndowia, } \\
28: 320\end{array}$ \\
\hline $\begin{array}{l}\text { S. physocarpi } \\
\text { (MFLUCC 14-0625) }\end{array}$ & $\begin{array}{l}\text { Physocarpus opulifolius } \\
\text { (leaves, twigs and fruits) }\end{array}$ & $350-900$ & 3 septate & $\begin{array}{c}(10-) 15-16 \times \\
3.5-4.8(5)\end{array}$ & $5.5-8$ & $7-12$ & $12-14$ & In this study \\
\hline S. pistaciae & $\begin{array}{l}\text { Physocarpus opulifolius } \\
\text { (bud) }\end{array}$ & $>150$ & 4 septate & $\begin{array}{l}(15-) 17-20(-22) \\
\quad \times(4-) 4.5(-5)\end{array}$ & - & $10-14$ & $12-20$ & $\begin{array}{c}\text { Persoonia } 33 \\
2014\end{array}$ \\
\hline \multirow[t]{2}{*}{ S. rosae } & \multirow{2}{*}{$\begin{array}{l}\text { Rosa kalmiussica Chrshan. } \\
\text { \& Lasebna }\end{array}$} & \multirow[t]{2}{*}{$250-400$} & \multirow[t]{2}{*}{3 septate } & $12.5-16.5 \times 3.5-4$ & $7-10$ & $11-20$ & $9-19$ & $\begin{array}{l}\text { Nag Raj, } \\
1993\end{array}$ \\
\hline & & & & $10-15 \times 3-4$ & $5-9$ & $1-6.5$ & $1-8$ & Sutton, 1980 \\
\hline $\begin{array}{l}\text { S. rosae } \\
\text { (MFLUCC 14-0621) }\end{array}$ & Rosa sp. (branches) & $\begin{array}{c}250-400 \times \\
150-170\end{array}$ & 3 septate & $\begin{array}{c}(11-) 12-15 \times \\
3.5-4.5(-5)\end{array}$ & $5-7$ & $5-10(-10.4)$ & $5-7(-8)$ & In this study \\
\hline S. vaccinii & Vaccinium myrtillus & $>100$ & 3 septate & $13-18 \times 4.5-5.5$ & - & None & None & Sutton, 1980 \\
\hline
\end{tabular}

"_" no result 
In the present study, combined LSU and ITS alignment is used to resolve species relationships in Seimatosporium (Fig 1), following (Tanaka et al. 2011). The phylogenetic tree shows that our collection clearly groups with Seimatosporium. The application of molecular data can provide reliable genetic evidence to define species boundaries in taxonomic studies, as shown in this study. Combined multi-gene data phylogenies can better resolve the taxonomy of genera such as Seimatosporium (Tanaka et al. 2011).

Seimatosporium species are common as saprobes and pathogens on plants, but are not considered to be destructive foliar pathogens. For example, Vermisporium acutum (三 Seimatosporium acutum), was found on a single necrotic lesion on Eucalyptus nicholii leaves (Barber et al. 2003). Species of Seimatosporium have been reported from necrotic spots and associated with disease on branches, twigs, leaves and fruits (Bulgakov et al. 2014). Seimatosporium physocarpi causes leaf spots and grows on living and dying branches. Thus, the Seimatosporium species in this study cannot be considered as saprobic in nature. In temperate arid climate zones, many necrotrophic fungi are specific on host-plants and grow during the cold and wet seasons. Endophytes, may mostly be pathogens, but they often may be treated as saprobes by mycologists, because during the summer they can only be found on dead branches (Bulgakov et al. 2014). Leaf spots of eucalyptus caused by Vermisporium have been reported from the Southern Hemisphere (Barber et al. 2011), while Vermisporium quercinum was found on the bark of Quercus suber (Fagaceae) in Sardinia, Italy (Franceschini et al. 1995). Vermisporium tenzingii was reported from leaves of Osbeckia crinita from Darjeeling, India and Osbeckia stellata in Kaltani, Nepal (Wu \& Sutton 1996). Some species such as S. brevicentrum and S. eucalypti were associated with insect damaged leaves, presumably as secondary invaders of leaf tissue damaged previously by insects or as endophytes sporulating in necrotic tissues (Barber et al. 2011). These results suggest that species of Seimatosporium are not likely to be a serious commercial problem.

\section{Acknowledgements}

Chada Norphanphoun thanks for the Mushroom Research Foundation, Chiang Mai, Thailand, for supporting this research. Kevin D. Hyde thanks the Chinese Academy of Sciences, project number 2013T2S0030, for the award of Visiting Professorship for Senior International Scientists at Kunming Institute of Botany. We would like to thank Humidtropics, a CGIAR Research Program that aims to develop new opportunities for improved livelihoods in a sustainable environment, for partially funding this work. Thanks for Chaiwat To-anun, Ratchadawan Cheewangkoon, Putarak Chomnunti, Saranyaphat Boonmee, Rungtiwa Pookamsak, Li Junfu, Ausana Mapook, Saowaluck Tibpromma, Chonticha Singtripop and Sirinapa Konta for informative name information, cultures preparation and general assistance.

\section{References}

Ariyawansa HA, Hawksworth DL, Hyde KD, Jones EBG, Maharachchikumbura SSN, Manamgoda DS, Thambugala KM, Udayanga D, Camporesi E, Daranagama A, Jayawardena R, Liu JK, McKenzie EHC, Phookamsak R, Senanayake IC, Shivas RG, Tian Q, Xu JC. 2014 Epitypification and neotypification: guidelines with appropriate and inappropriate examples. Fungal Diversity 69: 57-91. DOI 10.1007/s13225-014-0315-4.

Barr ME. 1975 -Pestalosphaeria, a new genus in the Amphisphaeriaceae. Mycologia 67: 187-194.

Barr ME. 1990 - Prodromus to nonlichenized, pyrenomycetous members of class Hymenoascomycetes. Mycotaxon 39: 43-184.

Barber PA, Smith IW, Keane PJ. 2003 - Foliar diseases of Eucalyptus spp. grown for ornamental cut foliage. Australasian Plant Pathology 32: 109- 111.

Barber PA, Crous PW, Groenewald JZ, Pascoe IG, Keane P. 2011 - Reassessing Vermisporium (Amphisphaeriaceae), a genus of foliar pathogens of eucalypts. Persoonia 27: 90-118. http://dx.doi.org/10.3767/003158511X617381.

Brockmann I. 1976 - Untersuchungen über die Gattung Discostroma Clements (Ascomycetes). Sydowia 28: 275-338. 
Bulgakov TS, Vasilyev NP, Zmitrovich IV. 2014 - Summarizing of 10-years investigation on mycobiota of alien trees and shrubs in arboretum of the «Otradnoye» Research Station of the Komarov Botanical Institute. Botany: History, Theory, Practice» (the 300th anniversary of the Botanical Institute. Komarov, Russian Academy of Sciences): Proceedings of the International Conference / Ed. DV Geltman. Saint-Petersburg: Publishing house 'LETI'. p. 31-39. [in Russian]

Cai L, Hyde KD, Taylor PWJ, Weir BS, Waller J, Abang MM, Zhang JZ, Yang YL, Phoulivong S, Liu ZY, Prihastuti H, Shivas RG, McKenzie EHC, Johnston PR. 2009 - A polyphasic approach for studying Colletotrichum. Fungal Diversity 39: 183-204.

Chomnunti P, Hongsanan S, Hudson BA, Tian Q, Persoh D, Dhami MK, Alias AS, Xu J, Liu X, Stadler M, Hyde KD. 2014 - The Sooty Moulds. Fungal Diversity 66:1-36.

Corda ACJ. 1833 - In J. Sturm, Deutschlands Flora in Abbidungen nach der Natur mit Beschreibungen III. (Pilze) 3(13): 65-96.

Crous PW, Shivas RG, Quaedvlieg W, van der Bank M, Zhang Y, Summerell BA, Guarro J, Wingfield MJ, Wood AR, Alfenas AC, Braun U, Cano-Lira JF, García D, Marin-Felix Y, Alvarado P, Andrade JP, Armengol J, Assefa A, den Breeÿen A, Camele I, Cheewangkoon R, De Souza JT, Duong TA, Esteve-Raventós F, Fournier J, Frisullo S, García-Jiménez J, Gardiennet A, Gené J, Hernández-Restrepo M, Hirooka Y, Hospenthal DR, King A, Lechat C, Lombard L, Mang SM, Marbach PAS, Marincowitz S, Marin-Felix Y, Montaño-Mata NJ, Moreno G, Perez CA, Pérez Sierra AM, Robertson JL, Roux J, Rubio E, Schumacher RK, Stchigel AM, Sutton DA, Tan YP, Thompson EH, van der Linde E, Walker AK, Walker DM, Wickes BL, Wong PTW, Groenewald JZ. 2014 - Fungal planet description sheets: 214-280. Persoonia 32:184-306.

Felsenstein J. 1985 - Confidence limits on phylogenies: An approach using the bootstrap. Evolution 39: 783-791. http://dx.doi.org/10.2307/2408678.

Franceschini A, Marras F, Sutton BC. 1995 - Notes of fungi of cork oak (Quercus suber L.) in Sardinia (Italy). IV Vermisporium quercinum sp. nov. Bulletin OILB/SROP 18: 14-17.

Hyde KD, McKenzie EHC, KoKo TW. 2011 - Towards incorporating anamorphic fungi in a natural classification - checklist and notes for 2010. Mycosphere 2(1), 1-88.

Index Fungorum (2015). www.indexfungorum.org - 2015.

Jayasiri SC, Ariyawansa HA, Liu JK, Jones EBG, Hyde KD. 2015 - The Faces of Fungi database: Fungal names linked with morphology, molecular and human attributes. Fungal Diversity (in press).

Jeewon R, Liew ECY, Hyde KD. 2002 - Phylogenetic relationships of Pestalotiopsis and allied genera inferred from ribosomal DNA sequences and morphological characters. Molecular Phylogenetics and Evolution 25: 378-392.

Jeewon R, Liew ECY, Simpson JA, Hodgkiss IJ, Hyde KD. 2003 - Phylogenetic significance of morphological characters in the taxonomy of Pestalotiopsis species. Molecular Phylogenetics and Evolution 27:372-383.

Kishino H, Hasegawa M. 1989 - Evaluation of the maximum likelihood estimate of the evolutionary tree topologies from DNA sequence data, and the branching order in Hominoidea. Journal of Molecular Evolution 29: 170-179. http://dx.doi.org/10.1007/BF02100115.

Maharachchikumbura SSN, Guo LD, Cai L, Chukeatirote E, Wu WP, Sun X, Crous PW, Bhat DJ, McKenzie EHC, Bahkali AH, Hyde KD. 2012 - A multi-locus backbone tree for Pestalotiopsis, with a polyphasic characterization of 14 new species. Fungal Diversity 56: 95-129.

Maharachchikumbura SSN, Guo LD, Chukeatirote E, Hyde KD. 2013 - Improving the backbone tree for the genus Pestalotiopsis; addition of $P$. steyaertii and P. magna sp. nov. Mycological Progress 13: 617-624.

Maharachchikumbura SSN, Hyde KD, Groenewald JZ, Xu J, Crous PW. 2014 - Pestalotiopsis revisited. Studies in Mycology 79: 121-186. 
Maharachchikumbura SSN, Hyde KD, Jones EBG, McKenzie EHC, Huang SK, Abdel-Wahab MA, Daranagama DA, Dayarathne M, D'souza MJ, Goonasekara ID, Hongsanan S, Jayawardena RS, Kirk PM, Konta S, Liu JK, Liu ZY, Norphanphoun C, Pang KL, Perera RH, Senanayake IC, Shang Q, Shenoy BD, Xiao Y, Bahkali AH, Kang J, Somrothipol S, Suetrong S, Wen T, Xu J. 2015 - Towards a natural classification and backbone tree for Sordariomycetes. Fungal Diversity. 72: 199-301.

Melnik VA. 1997 - Class Coelomycetes. Rare and little-known genera. Nauka, St.-Petersburg. P. 218-223.

Mordue JEM. 1985 - An unusual species of Pestalotiopsis: P. steyaertii sp. nov. Transactions of the British Mycological Society 85: 378-380.

Mordue JEM. 1986 - Another unusual species of Pestalotiopsis: P. montellicoides sp. nov. Transactions of the British Mycological Society 86: 665-668.

Nag Raj TR. 1985 - Redisposals and redescriptions in the Monchaetia-Seiridium, PestalotiaPestalotiopsis complexes I. The correct name for the type species of Pestalotiopsis. Mycotaxon 22: 43-51.

Nag Raj TR. 1986 - Redisposals and redescriptions in the Monchaetia-Seiridium, PestalotiaPestalotiopsis complexes. VII. Pestalotia citrini, P. maura and Pestalotia uvicola. Mycotaxon 26: 211-222.

Nag Raj TR. 1993 - Coelomycetous anamorphs with appendage-bearing conidia. Mycologue Publications, Waterloo, Ontario, Canada.

Nylander JAA. 2004 - MrModeltest v2.2. Program distributed by the author: 2. Evolutionary Biology Centre, Uppsala University: 1-2.

Page RDM. 1996 - Tree View: an application to display phylogenetic trees on personal computers. Computer Applications in the Biosciences 12: 357-358.

Paulus BC, Gadek PA, Hyde KD. 2006 - Discostromaficicola sp. nov. (Amphisphaeriaceae) and a key to species of Discostroma. Sydowia 58: 76-90.

Ronquist F, Teslenko M, van der Mark P, Ayres DL, Darling A, Höhna S, Larget B, Liu L, Suchard MA, Huelsenbeck JP. 2012 - MrBayes 3.2: efficient Bayesian phylogenetic inference and model choice across a large model space. Systematic Biology 61(3):539-542.

Senanayake IC, Maharachchikumbura SSN., Hyde KD, Bhat JD, Jones EBG., Mckenzie EHC., Dai DQ, Daranagama DA, Dayarathne MC, Goonasekara ID, Konta S, Li WJ, Shang QJ, Stadler M, Wijayawardene NN,. Xiao YP, Norphanphoun C, Li QR, Liu XZ, Bahkali AH, Kang JC, Wang Y., Wen TC, Xu JC, Camporesi E. 2015 - Towards unraveling relationships in Xylariomycetidae (Sordariomycetes). Fungal Diversity (In press)

Shoemaker RA, Müller E. 1964 - Generic correlations and concepts: Clathridium (= Griphosphaeria) and Seimatosporium (= Sporocadus). Canadian Journal of Botany 42: 403-410.

Sutton BC. 1980 - The coelomycetes: fungi imperfecti with pycnidia, acervular and stromata. Commonwealth Mycological Institute, Kew.

Swart HJ, Williamson MA. 1983 - Australian leaf-inhabiting fungi XVI. Vermisporium, a new genus of coelomycetes on Eucalyptus leaves. Transactions of the British Mycological Society 81: 491-502.

Swofford DL. 2002 - PAUP* 4.0: phylogenetic analysis using parsimony (* and other methods). Sinauer Associates, Sunderland.

Tanaka K, Endo M, Hirayama K, Okane I, Hosoya T, Sato T. 2011 - Phylogeny of Discosia and Seimatosporium, and introduction of Adisciso and Immersidiscosia genera nova. Persoonia 26, 2011: 85-98.

Telle S, Thines M. 2011 - Reclassification of an enigmatic downy mildew species on lovegrass (Eragrostis) to the new genus Eraphthora, with a key to the genera of the Peronosporaceae. Mycological Progress, doi:10.1007/s11557-010-0735-9.

Tomoshevich MA. 2012 - Atlas of plant-pathogenic fungi on arboreal plants in Siberia. Novosibirsk, publishing house 'Geo'. p. 213-214. 
Venkatasubbaiah P, Grand LF, Dyke CGV. 1991 - A new species of Pestalotiopsis on Oenothera. Mycologia 83(4):511-513

Vilgalys R, Hester M. 1990 - Rapid genetic identification and mapping of enzymatically amplified ribosomal DNA from several Cryptococcus species. Journal of Bacteriology 172(8): 4238-4246.

White T, Bruns T, Lee S, Taylor J. 1990 - Amplification and direct sequencing of fungal ribosomal RNA genes for phylogenetics. PCR Protocols: A Guide to Methods and Applications 18:315-322.

Winter G. 1887 - Pilze; Ascomyceten. In: Rabenhorst's Kryptogamen-Flora von Deutschland, Oesterreich und der Schweiz [i-vi] 1(2): 1-928

Wu WP, Sutton BC. 1996 - A reassessment of some Discosia species. Mycological Research 100: 287-290. 